\begin{tabular}{l} 
SOCIAL SCIENCES \& HUMANITIES \\
Journal homepage: http://www.pertanika.upm.edu.my/ \\
\hline PERTANIKA
\end{tabular}

\title{
Teaching and Learning Aids to Support the Deaf Students Studying Islamic Education
}

\section{Izuli Dzulkifli}

Research Centre for Quran and Sunnah, Faculty of Islamic Studies, Universiti Kebangsaan Malaysia (UKM), 43600 Bangi, Selangor, Malaysia

\begin{abstract}
Islamic Education's formal teaching and learning for deaf students in schools are based on the Special Education Curriculum. In order to improve the achievement in the teaching and learning of deaf students, teachers should utilize teaching aids that are appropriate to the learning content and the students' ability. The objective of this study is to explore the use of teaching aids by teachers teaching Islamic Education subjects to deaf students at the primary school level in Selangor. This study utilized the qualitative approach in the form of case studies by using the interview technique and document analysis to obtain data. Seven teachers from schools offering the Special Education Integration Program (Program Pendidikan Khas Integrasi) and one teacher from the Special Education School (Sekolah Pendidikan Khas) were selected as study respondents. The study respondents were selected based on the purposive sampling technique and had at least five years of teaching experience in Islamic Education subjects to deaf students. The findings showed there were several main types of teaching aids used by the respondents. They were printed materials, the use of Information and Communication Technology and by-product materials. The study also discovered several challenges faced by the respondents when using the teaching aids such as lack of appropriate and limited materials as well as the information and communication technology software was less friendly to deaf students in the learning of Islamic Education. This study contributes in terms of the recommendations of the production of appropriate teaching aids

ARTICLE INFO

Article history:

Received: 20 March 2021

Accepted: 30 August 2021

Published: 03 December 2021

DOI: https://doi.org/10.47836/pjssh.29.4.09

E-mail address:

izuli@ukm.edu.my in order to assist teachers in teaching and helping to improve students' achievement in Islamic Education learning.

Keywords: Deaf students, Islamic education, teaching aids, teaching and learning
\end{abstract}




\section{INTRODUCTION}

In Malaysia, deaf students are identified as having a hearing impairment and confirmed by a physician, audiologist, or psychologist. Some deaf students suffer from other disabilities such as speech, language, and communication (Hidayat et al., 2017). Deaf students are given formal learning facilities in Special Education Schools known as Sekolah Pendidikan Khas and in schools that offer the Special Education Integration Program known as Program Pendidikan Khas Integrasi, especially at the primary school. The Education Act (Federal Government Gazette, 2013) stipulates that if an educational institution has five or more Muslim students, then the students shall be taught Islamic Education subjects by teachers approved by the State Authority. The teaching and learning of Islamic Education subjects in schools involve several fields such as Quran, Akidah, Ibadah, Adab, Sirah, and Jawi (Ministry of Education Malaysia, 2004). Islamic Education is very important as a process of filling the soul or spirituality for a Muslim individual. It coincides with the Philosophy of Islamic Education itself, which is to educate students to master the knowledge, practices, and skills in life that have been set so that the subject of Islamic Education can contribute towards the molding of a Muslim who is knowledgeable, faithful, civilized, virtuous, skilled, responsible, charitable, pious and dedicated.

Based on the above, with no exception, every Muslim student, including deaf, is to learn Islamic Education subjects. Among the six fields of Islamic Education subjects, the Quran and the Akidah fields are the most difficult to learn by deaf students (Dzulkifli et al., 2020). The Quran requires students to pronounce and recite the Quran, while these are their main problems because they cannot hear and recite without the help of hearing aids. It is difficult to convey to deaf students, especially in the field of Akidah, where some abstract matters such as reward, sin, disbelieving in Allah, and others due to their limited vocabulary in the sign language which cause the teachers to lack words to explain some terms (Awang, 2017). Difficulty in understanding the abstracts can cause deaf students to be left behind in learning Islamic Education.

\section{LITERATURE REVIEW}

Most deaf students have difficulty learning to read and understand the content of learning due to hearing loss. The levels of hearing loss of deaf students are varied (Yasin et al., 2017). According to Ahmad (2012), the various levels of hearing loss of these deaf students are mild, moderate, severe, and profoundly deaf. Students with a mild level of hearing can still hear a little between a distance of one to 1.5 meters, and for the moderate level, the students need a loud voice in conversations while the students with a severe level can hear only loud sounds. In addition, deaf students cannot understand oral speech well if they do not use hearing aids, and only a small number can capture the meaning from lip movements, and they can also understand it 
through the remaining hearing residue that they still have (Ntinda et al., 2019).

In this regard, teachers face various challenges in delivering lessons to deaf students to accommodate the hearing loss levels. The learning objectives of Islamic Education are difficult to achieve if the teaching methods are channeled to deaf students due to the hearing difficulties they are experiencing. To ensure the teaching and learning process of Islamic Education can be implemented well, teachers should clearly understand the strategies that involve appropriate approaches, methods, and techniques to teach the students. With the combination of various teaching strategies that involve approaches, methods, and techniques, effective teaching can be conducted, and students can be attracted to learning.

Teachers' effective teaching is important in ensuring that students can achieve the learning objectives of a topic. Therefore, teachers need to diversify their teaching strategies to attract students to learn a particular field or subject (Noreen \& Rana, 2019). Teaching strategies require planning skills and managing teaching methods and techniques to ensure learning outcomes are achieved (Lom, 2012). Among the teaching strategies that can be used are teachercentered teaching strategies, studentcentered teaching strategies, materialcentered teaching strategies, task-centered teaching strategies, and activity-centered strategies. Material-centered teaching strategies involve teachers planning to use various materials such as books, drawings, computers, resource centers, and others to conduct teaching (Abbas et al., 2019). Important material-centered teaching strategies will assist teachers in meeting the learning needs of students with hearing problems.

Through material-centered teaching strategies, teachers can provide several mediums for students to learn based on their abilities, at the right time, and the right location (Adi et al., 2017). Teachers can also use various materials such as books, building blocks, drawing materials, scientific equipment, computers, resource centers, self-access centers, and others to conduct their teaching. Material-centered strategies include a wide range of ways for teachers to guide until those who learn individually can learn. In general, teaching materials can be classified into teaching aids in the form of patterns and non-pattern teaching aids. The main teaching aids in patterns are textbooks, computers, and LCD (liquid crystal display). The use of sheet papers, pictures, and reference books are teaching aids that can be categorized as a form of by-product patterns (McGrath et al., 2016). At the same time, non-pattern teaching materials are charts, newspaper cuttings, exercise books, video, audio, real materials, black or whiteboards, and cards. Teaching aids can be categorized into two types, namely electronic and non-electronic. The use of radios, projectors and slides, televisions and computer-based devices are teaching aids of the electronic type. In contrast, magazines, pictures, scan cards, and journals are the non-electronic type (Alias et al., 2016). 
The use of teaching aids can attract students' interest in learning a topic or field of learning (Khairuddin et al., 2018). Among the main materials in the teaching and learning of Islamic Education in mainstream schools are textbooks. Teaching aids are very important especially to the students who still have a little ability in hearing and speaking. They can be trained to pronounce the correct words/sounds by using modern technological tools (Seman et al., 2019). Every teacher needs to improve and diversify teaching materials in addition to textbooks in delivering lessons to students. The improvements include the improvement of the quality of more sophisticated learning materials using the use of information and communication technology tools such as the internet, computers, interactive videos and materials in websites (Nor \& Sharif, 2014). Therefore, every teacher needs to diversify the use of teaching aids or teaching materials to attract deaf students to study Islamic Education. The role of teachers to produce and provide teaching aids in Islamic Education subjects for deaf students should be given attention. This is because material-centered teaching strategies can help improve students' achievement in learning. The teaching and learning of Islamic Education for deaf students need to grow in line with the development of the current technological tools such as computers, tabs, and laptops, as well as assisted by internet facilities, websites, and compact discs that are suitable for students with hearing impairment (Azzamilli \& Bazazoo, 2013).
Hence, this study explores teaching materials teachers used in teaching Islamic Education subjects to deaf students in the national schools. In addition, this study aims to explain the challenges faced by teachers in applying material-centered teaching strategies in the teaching and learning of Islamic Education subjects to deaf students.

\section{METHODS}

This study utilized the qualitative approach in a case study using semi-structured interviews and document analysis to obtain data. Eight respondents were selected based on purposive sampling who had at least five years of experience in teaching Islamic Education to deaf students in primary schools in Selangor, as shown in Table 1 below.

The above data shows that eight teachers who met the criteria were selected after receiving information through the Selangor State Education Department and the headmasters. The document analysis was based on documents related to the teaching and learning for deaf students, such as circulars from the Ministry of Education Malaysia, syllabus, and teaching record books obtained from several respondents to strengthen the interview data further. The choice of the study area in Selangor was based on the most prevalent number of deaf students studying in the said state in Malaysia, as shown in Table 2.

The following semi-structured interview questions were presented to obtain data on teaching aids used by the study respondents: 1. How do you plan the teaching of 
Table 1

Respondents'demographic information

\begin{tabular}{ccccc}
\hline Teacher & Sex & Age & $\begin{array}{c}\text { Experience in teaching islamic } \\
\text { education for deaf students }\end{array}$ & Type of school \\
\hline No.1 & Female & 35 & 5 Years & PPKI \\
No.2 & Female & 42 & 21 Years & $P P K I$ \\
No.3 & Female & 45 & 12 Years & $P P K I$ \\
No.4 & Female & 38 & 12 Years & $P P K I$ \\
No.5 & Female & 50 & 7 Years & PPKI \\
No.6 & Female & 47 & 5 Years & PPKI \\
No.7 & Male & 36 & 7 Years & PPKI \\
No.8 & Male & 34 & 8 Years & SKPK \\
\hline
\end{tabular}

Note: PPKI-Program Pendidikan Khas Integrasi, SKPK-Sekolah Kebangsaan Pendidikan Khas

Table 2

Number of deaf students in primary schools by state

\begin{tabular}{|c|c|c|c|c|c|}
\hline \multirow{3}{*}{ No } & \multirow{3}{*}{ State } & \multicolumn{4}{|c|}{ Types of School } \\
\hline & & \multicolumn{2}{|c|}{$P P K I$} & \multicolumn{2}{|c|}{$S K P K$} \\
\hline & & $\mathrm{M}$ & $\mathrm{F}$ & $\mathrm{M}$ & $\mathrm{F}$ \\
\hline $\mathrm{i}$ & Johor & 46 & 34 & 41 & 27 \\
\hline ii & Kedah & 13 & 21 & 36 & 44 \\
\hline iii & Kelantan & 30 & 28 & 14 & 11 \\
\hline iv & Melaka & 16 & 9 & 12 & 11 \\
\hline $\mathrm{v}$ & Negeri Sembilan & 11 & 5 & 13 & 14 \\
\hline vi & Pahang & 16 & 21 & 15 & 16 \\
\hline vii & Perak & 49 & 45 & 13 & 22 \\
\hline viii & Perlis & - & - & 9 & 9 \\
\hline ix & Pulau Pinang & 16 & 14 & 12 & 16 \\
\hline $\mathrm{x}$ & Sabah & 23 & 16 & 38 & 40 \\
\hline $\mathrm{xi}$ & Sarawak & 22 & 13 & 34 & 30 \\
\hline xii & Selangor & 77 & 72 & 29 & 25 \\
\hline xiii & Terengganu & 15 & 12 & 17 & 32 \\
\hline xiv & WP Kuala Lumpur & 14 & 3 & 24 & 29 \\
\hline $\mathrm{xv}$ & WP Labuan & 3 & 4 & - & - \\
\hline xvi & WP Putrajaya & 13 & 13 & - & - \\
\hline \multirow{2}{*}{\multicolumn{2}{|c|}{ Total }} & 364 & 310 & 307 & 326 \\
\hline & & \multicolumn{2}{|c|}{674} & \multicolumn{2}{|c|}{633} \\
\hline
\end{tabular}

Source: Special Education Data Year 2020, Ministry of Education Malaysia

Note: DE-Deaf, M-Male, F-Female, PPKI-Program Pendidikan Khas Integrasi, SKPK-Sekolah Kebangsaan Pendidikan Khas

Islamic Education to deaf students in your 3. What apps or software do you commonly classroom? 2. What teaching materials do use when teaching Islamic Education you use when teaching Islamic Education subjects to students? 4. What challenges do subjects to the students in the classroom? you face in using the teaching aid materials 
when teaching Islamic Education subject to the students?

\section{FINDINGS}

The study's findings showed that the respondents had used several teaching materials during Islamic Education teaching and learning sessions to the students. The types of teaching materials used by the respondents were categorized into three types. The first type was the printed teaching materials such as textbooks, pictures, scan cards, and worksheets. The second type was the use of Information and Communication Technology materials such as computers and tabs. The third type was the use of byproducts such as the use of clay or plasticine. The types of teaching aids and materials used by teachers during Islamic Education teaching and learning sessions to deaf students are shown in Table 3 below.

Table 3

Types of teaching aids during the Islamic education teaching and learning sessions

\begin{tabular}{ccc}
\hline No & Type & Item \\
\hline & & Textbooks \\
1 & Printed Material & Scan Cards \\
& & Worksheets \\
\hline & Information and & Desktop Computers \\
2 & Communication & Laptop \\
& Technology & Tab \\
& & YouTube Channel \\
\hline 3 & By-Product & Clay \\
\hline
\end{tabular}

\section{Textbook}

The use of textbooks as teaching aids was obtained through interview data with Teachers No. 3, No.5, No.6, and No.8.
Usually, I use textbooks. Because in the textbook, there are already hand gesture pictures. So, students can learn from there. (Interview: T3)

I use textbooks provided by the Ministry of Education Malaysia to teach Islamic Education. (Interview: T5)

If students cannot hear, I teach them by using the methods in the textbook. (Interview: T6)

Usually, I use textbooks as the main teaching materials to teach deaf students. (Interview: T8)

\section{Pictures}

In addition, the respondents also used pictorial materials such as sample interview data with Teacher No. 4.

So far, I have used the method of picture prints of hijaiyyah letters or words from the Quranic verses. I paste the pictures in front of the class. And I will teach them using Sign Language. (Interview: T4)

\section{Scan Cards}

In addition, the use of scan cards as teaching aids is obtained through interview data with Teachers No.1, No.3, No.5, and No.7.

Usually, I use more scan cards such as letter cards and verse cards from the Quran. Because it is easier for students to see, because many of my 
students do not hear, so I rarely use video. (Interview: T1)

I increase the use of letters and words scan cards because they can attract students' interest. (Interview: T3)

I also use other materials such as scan cards. (Interview: T5)

I planned lessons by arranging cards in front of the class, especially for the area of the Quran. If the student can speak out, he will recite them little by little. Those who cannot speak will arrange the letters alif and follow the sequence with the letter ba. (Interview: T7)

\section{Worksheets}

Teacher No.5 uses worksheets as one of the teaching materials.

Sometimes I also distribute worksheets. In the worksheets, there are matching and pairing activities, connecting letters and even words. (Interview: T5)

In addition to printed materials, the respondents also used visual materials or Information and Communication Technology tools during Islamic Education teaching and learning sessions in the classroom. Most deaf students cannot hear well, so the visual learning approach is very suitable for them. The use of Information and Communication Technology tools can attract the interest of deaf students to study Islamic Education subjects.

\section{Desktop Computers}

Among the respondents' use of Information and Communication Technology tools were using computers as examples of interview data with Teachers No.1, No.2, and No.6.
I also use desktop computers in teaching. Sometimes I tell students to learn to type on the computer. (Interview: T1)
Usually, in a week, there are three meetings, and the least, I use the computer during teaching. (Interview: T2)
My first strategy is to use teaching aids through computers. I first show the learning content to the students, and then I start the teaching session. (Interview: T6)

\section{Laptop}

The use of desktop computers may be less popular with some respondents for the desktops require suitable computer space to be connected to monitors, keyboards, and mouse. Hence, some respondents used laptops or tabs as alternatives in teaching Islamic Education in the classroom. In addition, laptops and tabs are smaller than desktops with built-in monitors, keyboards, and mouse. These make the laptop and tab lighter and easier to carry anywhere for teachers to use. Hence, some respondents use computer laptops. These were obtained through interview data from Teacher No.4. 
I only use laptops because there are not many students in the class. So, all students can focus on one laptop only. (Interview: G4)

\section{Tab}

Teachers also use tabs as alternative tools during the teaching and learning activities as acquired from interview data from Teacher No. 5.

I use tabs to show the learning content through a video display.

These students really like watching videos. (Interview: T5)

Visual learning is synonymous with deaf students because they cannot hear well. Therefore, some respondents chose visual materials that can attract students' interest to learn Islamic Education subjects as obtained from the interview data with Teacher No.2, No.4, and No.8.

If we only use textbooks, these students would not be attracted. With computers, I showed them stories related to Islamic history, morals, and others. (Interview: G2)

Deaf students are learning more visually as they are visual learners. So, I teach them more through visual materials because it can attract their interests. (Interview: G4)

Usually, deaf students, understanding is based on visuals because they cannot hear. For the area of the Quran, I include a video on the recitation of the Quran using Sign Language. (Interview: G8)

\section{YouTube Channel}

To optimize the use of Information and Communication Technology, some respondents opened YouTube channels, videos, or used power points in teaching. It was obtained from interview data with Teachers No.3, No.5, and No.6.

I switched on videos on YouTube. I directed them to certain verses for the learning of the Quran using hijaiyyah letters. Although they cannot hear, indirectly, they can also learn the hijaiyah letters. (Interview: T3)

I switched on the video from the YouTube channel. However, videos teaching Islamic Education using sign language are not many. (Interview: T5)

Usually, I will switch on a video on a verse from the Quran. At times, I switch on cartoons that recitel read certain verses on the YouTube channel. (Interview: T6)

\section{By-product Materials (Plasticine)}

Some respondents used by-product materials Plasticine (clay) as teaching materials in the area of the Quran. The use of the materials was to introduce the Hijaiyyah letters to deaf students. These findings were obtained through joint interview data with Teacher No.4. 
Usually, I use power points and pictures in teaching. But if the students are level one or year one, I give them plasticine for them to learn to form letters and words from the Al-Quran. (Interview: T4)

The use of Information and Communication Technology should be emphasized in the teaching and learning of Islamic Education for deaf students. The use of Information and Communication Technology in schools is a learning element stated in the content of the Special Education Primary School Standard Curriculum. It was supported by the analysis of the Special Education Primary School Standard Curriculum (Hearing Impairment) document for Islamic Education 2017, which states:

Cross-Curriculum Elements are valueadded elements inculcated in the teaching and learning process (T\&L) in addition to those specified in the standard content. These elements are inculcated with the aim of strengthening the desired human capital skills and competencies as desired well as being able to address current and future challenges. The elements in CrossCurriculum Elements are as follows:

Information and Communication Technology

- The inculcation of ICT elements in T\&L ensures that students can apply and strengthen the basic knowledge and skills of ICT learned.

- The application of ICT not only encourages students to be creative but also makes T\&L more interesting and fun and, at the same time, improves the quality of learning.

- ICT is integrated according to the suitability of the topic to be taught and as an enabler to further enhance students' understanding of the subject content.

Material-centered teaching obtained through interviews with respondents to teach Islamic Education subjects to deaf students was supported by the analysis of the Education (Special Education) Regulations 2013 document as follows: Implementation of Special Education (1) For the purpose of implementing Special Education -

(a) any person involved in the implementation of Special Education shall use the Special Education Curriculum;

(b) a teacher must use the Individual Education Plan: and

(c) a teacher may make modifications to -

(i) teaching or learning methods or techniques;

(ii) the time allotted for each activity;

(iii) arrangement of activities; and

(iv) teaching aids.

(2) Any modifications made under paragraph (1) (c) shall be in accordance with the Special Education Curriculum. Source: Special Needs Student Education Code of Practice, Special 
Education Division Ministry of Education Malaysia 2014

As a result of this study, almost all respondents had used appropriate teaching materials as per the stipulations stated in the Special Education Regulations 2013. Among the teaching materials inculcated by teachers in teaching the students was through the Information and Communication Technology tools. For example, using a display on a computer screen helped the students understand more clearly by using their vision since they had a hearing impairment. In addition, the use of computers and the internet through Information and Communication Technology was used for drills, training, and games in learning. Other than that, slides or power points could help deaf students speed up their understanding more easily. The use of pictures, maps, and charts was able to attract the students' interests and helped them understand a learning topic well.

However, some teachers face some challenges in using the Islamic Education teaching and learning materials for deaf students because their hearing ability is not the same as typical students studying in mainstream schools. Therefore, teachers should provide teaching materials appropriate to the learning objectives, time, and ability of students and improve students' understanding of learning. Among the challenges faced by teachers in applying material-centered teaching in the teaching and learning of Islamic Education to deaf students are as follows:

\section{Limited Teaching Material Resources}

Material resources that are suitable teaching materials for deaf students to study Islamic Education subjects are difficult to find and limited. Most of the existing teaching aids are more suitable for typical students at mainstream schools. It was obtained from the following interview data.

\section{Resources for Teaching Aids are limited. Most that are available are for typical students. So, I have to use sources from textbooks and edit certain pictures for Teaching Aids. (Interview: T7)}

The pictures of hijaiyyah letters in textbooks are too small and not very clear. It is difficult for me to teach using the textbooks. These students also find it difficult to see those pictures. (Interview: T5)

I found there was a lack of existing teaching aids suitable for deaf students in learning Islamic Education, especially in the field of the Quran. (Interview: T8)

\section{Limited Time}

Teaching and learning Islamic Education is limited because teachers must also teach other fields such as the Akidah, Ibadah, Sirah, Adab, and Jawi, besides the Quran. Therefore, limited teaching time slightly affects the quality of teaching by teachers who are utilizing teaching aids. It is obtained through the following interview data: 
Deaf students often rely on pictures and simulations by teachers to master their skills, especially in the field of the Quran, because they cannot listen. Since time is limited, it is quite difficult to use Teaching Aids completely because, at the same time, we have to teach them the other fields using sign language and teach them by speaking. (Interview: T7)

\section{Various Characteristics of Deaf Students}

As there are some deaf students with different characteristics such as learning problems, Islamic Education teachers face challenges in delivering teacher-centered teaching aids during the teaching and learning sessions. It also affects the teaching session, which is based on teaching aids for other students as well. This situation was obtained through the following interview data:

My students definitely cannot hear, but there are also those with autism and hyperactive. I have to think and produce Teaching Aid Materials that suit the various characteristics of the students. (Interview: T1)

But if the students are deaf, we have to focus one by one. Even though there are only four students in the class, it is like teaching 40 students. Because some of them have learning difficulties. (Interview: T4)
Some of my students have other problems, such as learning problems. They forget previous learning a lot. So, to use Teaching Aid Materials that can be used for all students with such diversity at one time is quite difficult. (Interview: T5)

\section{Unfriendly Applications for Deaf}

Students. Although Information and Communication Technology facilities have expanded, there are still some Information and Communication Technology-based learning applications that are less friendly with deaf students. It is obtained from the following interview data.

It is difficult to find Islamic Education learning software that is suitable for deaf students. If there is suitable and interesting software, it can definitely facilitate the teachers' task. Students will also find it fun to learn. (Interview: T3)

It is difficult to find materials in digital form. So, I have to diversify the preparation of the teaching materials, which are more friendly with students so that they can be easily understood. (Interview: T4)

From the interview findings and document analysis above, teachers who teach Islamic Education can use and diversify the teaching methods to deaf students, including various teaching aids. However, teaching 
aids such as the suitability to students' ability, resource limitations, the diversity of student characteristics, and digital software that is less friendly to deaf students are among the challenges teachers face in applying material-centered teaching.

\section{DISCUSSION}

This study aims to explore the use of teaching aids used by teachers in teaching Islamic Education subjects to deaf students at the primary school level in Selangor. There are three main types of teaching aids used by teachers to teach Islamic Education to deaf students: the use of printed materials, the use of Information and Communication Technology, and the use of by-product materials. The use of printed teaching materials is picture textbooks, scan cards, and worksheets. The use of Information and Communication Technology materials are computers, tabs, and YouTube channels. The use of by-products is like clay or plasticine. Each individual or student has his/her style and way of learning. Therefore, teachers need to identify students' learning styles so they can learn better. By understanding students' learning styles, teachers can apply various teaching strategies or approaches that can attract students' interest in learning certain topics (Musyoka et al., 2016). By knowing the learning style of each student, teachers can help to predict what is the appropriate teaching approach to be applied by students who practice the learning style and formulate appropriate teaching strategies. One of the learning styles that can attract students' interest to learn is using teaching aid materials (Ghani \& Ahmad, 2013).

Material-centered teaching is also important to help teachers meet the diverse needs of students. Through materialcentered learning, teachers can provide a variety of ways for students to learn at their own pace, at any time, and in locations that do not complicate them (Nor et al., 2016). One of the main materials provided for students to learn Islamic Education in schools is textbooks. However, teachers also need to think of teaching aid materials in addition to textbooks that can help students who do not attend class on school days (Elhoshi et al., 2017). Recently, there has been an increase in the use of media and technology in material-centered teaching and learning. Such improvements include learning materials, learning guides, textbook guides, workbooks, videos, and learning packages. The more sophisticated materials are computer-based learning packages, computer conferences, compact disc, multimedia, computer discussion groups, interactive videos, in-site materials, teleconferences, video conferencing, and telematics. Therefore, it is very appropriate for every teacher to use teaching materials or teaching aids to attract deaf students' interest studying Islamic Education subjects either at school or home.

Since most deaf students do not hear well, the visual-based teaching and learning approach is very suitable. The use of image photos or photographs is one of the most important materials in communication that has been used in various events, 
including teaching (Alias et al., 2016). Image photography has become plenty of material for researchers and educators, especially those who interact with the hearing impaired (Yusof et al., 2014). The learning approach of deaf students is more inclined to visual learning. According to Alias et al. (2016), deaf students are more likely to use stationary visual and moving visual images as one approach in teaching and learning. According to him, although teachers use Sign Language while teaching in the classroom, deaf students need clear visual images to be applied to the teaching and learning process. In this case, teachers need to be wise in choosing the appropriate teaching materials so that the learning content delivery to the students will be more interesting (Ajmain et al., 2019). Several factors need to be considered before teachers can successfully select and implement material-centered teaching. Among the factors that influence the selection of teaching aids include teaching objectives, teaching time, teaching materials, students' background, and the number and arrangement of students (Apak $\&$ Taat, 2018). It is important to ensure the use of teaching aids used by teachers in assisting the teaching and learning process of Islamic Education as well as able to benefit the teachers and deaf students.

The teaching and learning process also involves aspects of listening by using audio applications to obtain information. It is one of the reasons for the use of audio in Islamic Education subjects during the teaching and learning process in the field of the Quran.
Students need to use their auditory senses to imitate the sounds of pronunciation and reading taught by teachers (Dzulkifli et al., 2020). Since deaf students cannot hear well due to their hearing impairment, teachers need to apply ICT as best as possible as teaching aids as appropriate to the hearing impairment of deaf students. The use of ICT can increase the interest of deaf students to learn either inside or outside the classroom. The use of ICT through computers, videos, pictures, and slides is very synonymous with the learning style of deaf students because they are not able to listen well (Azzamilli \& Bazazoo, 2013). Visual images displayed, such as the use of pictures, must be relevant to the learning content. The use of appropriate visual images in teaching and learning must have benefits to aid students' understanding as well as to ensure they truly understand its content (Kelly et al., 2019). In this case, teachers need to wisely choose pictures that have the meaning of the content of the pictures that can be easily understood. The pictures should also have a clear meaning to the students (Cooper et al., 2013).

Islamic Education teachers need to use materials or teaching aids appropriate to students (Abdullah et al., 2014). Among the things that need to be considered in determining teaching aid materials are age, gender, and the achievement level or the students' ability (Gremmen et al., 2016). It is very important because the teaching and learning of Islamic Education for deaf students are different from teaching the typical students in the mainstream. In order 
to produce suitable teaching materials, several basic things need to be given attention when producing Islamic Education teaching materials for deaf students. The use of colors, movements, examples, clear pictures, simple expressions, and appropriate images should be produced as teaching aids in Islamic Education subjects. The selection of appropriate teaching aids is also important in teaching to deliver the learning content (Caner \& Tertemiz, 2015). For example, if the lesson content is in the form of skills such as listening and speaking in Al-Quran, teachers should choose the appropriate teaching aid materials to practice these skills.

The integration of information and communication technology is one of the added values included in $21^{\text {st }}$-century teaching. Furthermore, integrating technology into teaching can promote student learning and teacher productivity (Aldunate \& Nussbaum, 2013). There are still research reports stating that teaching aids are still not enough, especially those involving the latest Information and Communication Technology (Yasin et al., 2013). The use of Information and Communication Technology is a way to improve the achievement and success of deaf students because without teaching aids, the teaching process will have less quality and ineffective that can affect the academic achievement of deaf students.

Older teachers or experienced teachers need to apply the use of Information and Communication Technology in line with the development of the digital world today in the teaching of Islamic Education to deaf students. Some older teachers do not want to change towards the integration of information and communication technology in schools compared to new teachers who are more information technology friendly (Seman et al., 2019). It shows that young people are more exposed to new technologies. It is due to some old teachers who are not ready for the new curriculum changes in using Information and Communication Technology applications in implementing teaching (Majid et al., 2017). The attitude of teachers who do not care for the latest teaching developments, causing some teachers to be not ready to provide and use teaching aids in teaching and learning in schools. By learning and adapting to the latest teaching developments such as mobile learning containing education and entertainment (Yusof et al., 2014), the teaching and learning of Islamic Education will be more effective for deaf students. In addition, teachers should strive to provide or produce teaching materials as teaching aids for Islamic Education, deepening the content to be taught and knowing how to teach Islamic Education learning to deaf students.

\section{CONCLUSION}

Material-centered teaching strategies are one of the teaching strategies used by teachers in the teaching and learning of Islamic Education. Teaching aids that are appropriate with the development of technology and communication can attract deaf students' interest to learn Islamic 
Education. However, every material or tool used in the teaching and learning of Islamic Education should be used as best as possible so that all the privileges and advantages of the materials can benefit the students. Most deaf students have different levels of hearing impairment; in fact, some even have other characteristics such as learning difficulties. Therefore, Islamic Education teachers must use teaching materials appropriate to the student's ability and level of disability. As deaf students' learning styles are more focused on visual forms, teachers need to take advantage of technological facilities in producing quality teaching aids. Therefore, various teaching materials can be used by teachers to convey the learning content of Islamic Education to deaf students. Several factors that influence the selection of teaching methods and techniques should also be emphasized, such as the various characteristics of the students, loss of hearing level, and speaking ability among deaf students. In other words, effective teaching depends on the teachers' own ability to teach well that can motivate students to continue learning. Teachers need to delve into the learning content and know-how to teach certain learning content. However, teachers need to provide teaching aids that are appropriate to the field found in the subject of Islamic Education. Teachers who teach deaf students should also be given training and related courses in producing teaching aid materials as appropriate to the area found in the subject of Islamic Education. The production of appropriate teaching materials can help the teachers' tasks in delivering the learning content and help to improve deaf students' achievement in learning Islamic Education.

\section{ACKNOWLEDGEMENT}

This article was published as part of a study from the National University of Malaysia Research Grant: GUP-2016-073.

\section{REFERENCES}

Abbas, L. N., Md Khair, S. N., \& Md Amin, N. D. (2019). Exploring the elements of multimedia needed for deaf and hearing-impaired students in polytechnics. Online Journal for TVET Practitioners, 4(20), 77-82.

Abdullah, M. K., Johari, K. H., Chuchu, A. Y. A., \& Laji, H. (2014). Komunikasi guru dalam bilik darjah dan tingkah laku delinkuen murid sekolah menengah [Teacher communication in the classroom and delinquent behavior of secondary school students]. Jurnal Pemikir Pendidikan, 5, 59-77.

Adi, S. S., Unsiah, F., \& Fadhilah, D. (2017). Teaching special students: English lessons for deaf students in Indonesian special junior high schools. International Journal of Education and Research, 5(12), 121-136.

Ahmad, A. (2012). Mengenal dan menangani orang kurang upaya [Recognizing and addressing people with disabilities]. Dewan Bahasa dan Pustaka.

Ajmain, M. T., Hehsan, A., \& Mohamad, A. M. (2019). Learning and facilitation (PdPc) Islamic education in industrial revolution 4.0. Journal of Research in Psychology, 1(3), 13-17. https://doi. org/10.31580/jrp.v1i3.975

Aldunate, R., \& Nussbaum, M. (2013). Teacher adoption of technology. Computers in Human Behavior, 29(3), 519-524. 
Alias, A., Sharif, N. M., Baharuddin, N. F., Hamzah, M. H. M., \& Zahari, F. (2016). Penerokaan kesan pengajaran dan pembelajaran menggunakan visual imej dalam kalangan pelajar cacat pendengaran [Exploring the effects of teaching and learning using visual images among hearing impaired children]. Jurnal Komunikasi, 32(1), 335 - 350. https://doi.org/10.17576/ jkmjc.2016-3201-16.

Apak, J., \& Taat, M. S. (2018). Pengaruh kesediaan guru terhadap pengurusan bilik darjah abad ke21 [The influence of teachers' readiness towards $21^{\text {st }}$ century classroom management]. Malaysian Journal of Social Sciences and Humanities, 3(4), 6-22.

Awang, M. H. (2017). Penghayatan Fardu Ain remaja pekak di Malaysia [Internalization of Fardu Ain among deaf teenagers in Malaysia, Doctoral thesis]. Akademi Pengajian Islam Universiti Malaya.

Azzamilli, Z. I. S., \& Bazazoo, H. N. (2013). Employing modern technology in teaching the Holy Quran to deaf students. In Proceedings of the 2013 Taibah University International Conference on Advances in Information Technology for the Holy Quran and Its Sciences (pp. 489-524). IEEE Computer Society.

Caner, H. A., \& Tertemiz, N. I. (2015). Beliefs, attitudes and classroom management: A study on prospective teachers. Procedia-Social and Behavioral Sciences, 186, 155-160.

Cooper, S. B., Cripps, J. H., \& Joel, I. (2013). Service-learning in deaf studies: Impact on the development of altruistic behaviors and social justice concern. American Annals of the Deaf, 157(5), 413-427. https://doi.org/10.1353/ aad.2013.003.

Dzulkifli, I., Suhid, A., Fakhruddin, F. M., \&Ahmad, N. A. (2020). Teacher communication in teaching al-Quran to special needs pupils with hearing disabilities. Universal Journal of
Educational Research, 8(1A), 36-43. https://doi. org/10.13189/ujer.2020.081306.

Elhoshi, E. R. F., Embong, R., \& Bioumy, N. (2017). The role of teachers in infusing Islamic values and ethics. International Journal of Academic Research in Business and Social Sciences, 7(5), 426-436.

Federal Government Gazette. (2013). Education (Special Education) Regulations 2013: The Education Act (1996, ACT 550, section 50). Attorney General's Chambers of Malaysia.

Ghani, M. Z., \& Ahmad, A. C. (2013). Kaedah dan strategi pengajaran kanak-kanak berkeperluan khas [Methods and strategies for teaching special needs children]. Penerbit Universiti Sains Malaysia.

Gremmen, M. C., Van den Berg, Y. H., Segers, E., \& Cillessen, A. H. (2016). Considerations for classroom seating arrangements and the role of teacher characteristics and beliefs. Social Psychology of Education, 19(4), 749-774.

Hidayat, L., Gunarhadi., \& Hidayatulloh, F. (2017). Multimedia based learning materials for deaf students. European journal of Special Education Research, 2(3), 77-87.

Kelly, C., Morgan, G., Freeth, M., Siegal, M., \& Matthews, D. (2019). The understanding of communicative intentions in children with severe-to-profound hearing loss. The Journal of Deaf Studies and Deaf Education, 24(3), 245-254.

Khairuddin, K. H., Miles, S., \& McCracken, W. (2018). Deaf learners' experiences in Malaysian schools: Access, equality and communication. Social Inclusion, 6(2), 46-55.

Lom, B. (2012). Classroom activities: Simple strategies to incorporate student-centered activities within undergraduate science lectures. The Journal of Undergraduate Neuroscience Education, 11(1), A64-A71. 
Majid, F. A., Zamin, A. A. M., \& Kamaruddin, F. (2017). Toolkits for 21st century teaching: Practical implications for the 4th industry skill developments. Penerbit Press UiTM.

McGrath, A., Hollier, S., \& Leigh, G. (2016). The integration of captioned multimedia and auditory access technologies for deaf and hard of hearing students and mainstream classrooms. Special Education Perspectives Journal, 25(1), 18-30.

Ministry of Education Malaysia. (2004). Sukatan pelajaran Pendidikan Islam KBSR [KBSR Islamic education syllabus]. Dewan Bahasa dan Pustaka.

Ministry of Education Malaysia. (2007). Maklumat pendidikan khas [Special education information]. Bahagian Pendidikan Khas, MOE.

Musyoka, M. M., Gentry, M. A., \& Bartlett, J. J. (2016). Voices from the classroom: Experiences of teachers of deaf students with additional disabilities. Journal of Education and Training Studies, 4(2), 85-96.

Nor, A. M., \& Sharif, S. (2014). Penggunaan bahan visual di kalangan guru teknikal [Visual aids usage among technical education teachers]. Jurnal Pemikir Pendidikan, 5, 79-98.

Nor, M. M., Rahman, A. M. N, Nor, M. N., Talha, M. N., \& Razak, A. Z. (2016). Amalan kepimpinan pengajaran untuk penambahbaikan sekolah: Retrospeksi guru besar sekolah berprestasi tinggi [Instructional leadership practises for school improvement: restrospect of high performing schools' headmasters]. Fakulti Pendidikan, Universiti Malaya.
Noreen, R., \& Rana, A. M. K. (2019). Activity-based teaching versus traditional method of teaching in mathematics at elementary level. Bulletin of Education and Research, 41(2), 145-159.

Ntinda, K., Thwala, S. K., \& Tfusi, B. (2019). Experiences of teachers of deaf and hard-ofhearing students' in a special needs school: An exploratory study. Journal of Education and Training Studies, 7(7), 79-89. https://doi. org/10.11114/jets.v7i7.4274

Seman, N. H., Idris, M. Z., Daud, M. I., Ab. Rahman, N. A. N., \& Rahman, M. N. A. (2019). Teaching al-Quran to deaf students: Challenges for Islamic Education teachers. Online Journal of Islamic Education, 7(1), 46-53.

Yasin, M. H. M., Toran, H., Tahar, M. M., Bari, S., Ibrahim, S. N. D., \& Zaharudin, R. (2013). Bilik darjah pendidikan khas pada masa kini dan kekangannya terhadap proses pengajaran [Current special education classroom and its limitations towards teaching process]. Asia Pacific Journal of Educators and Education, 28, 1-9.

Yasin, M. H. M., Tahar, M. M., Bari, S., \& Manaf, F. N. (2017). The sign language learning in deaf student and special education teacher in integration program of hearing problem. Journal of ICSAR, 1(2), 166-174.

Yusof, A. M., Daniel, E. G. S., Low, W. Y., \& Ab. Aziz, K. (2014). Teachers' perception of mobile edutainment for special needs learners: The Malaysian case. International Journal of Inclusive Education, 18(12), 1237-1246. 
